\title{
Diversity of Papaya ringspot virus Isolates in Puerto Rico
}

\author{
Cristina Zambrana-Echevarría, Lorriane De Jesús-Kim, \\ Rocio Márquez-Karry, and Dimuth Siritunga ${ }^{2}$ \\ University of Puerto Rico Mayagüez, Mayagüez 00681, Puerto Rico
}

\author{
David Jenkins ${ }^{1}$ \\ USDA-ARS, Tropical Agriculture Research Station, Mayagüez 00681, \\ Puerto Rico
}

Additional index words. Carica papaya, Papaya ringspot virus, PRSV, coat protein gene, Puerto Rico, diversity

\begin{abstract}
Papaya ringspot virus (PRSV) devastates papaya production worldwide. In Puerto Rico, papaya fields can be completely infected with PRSV within a year of planting. Information about the diversity of the Puerto Rican PRSV (PR-PRSV) population is relevant to establish a control strategy in the island. The coat protein gene (cp) of PRSV was sequenced from 62 isolates from different regions in Puerto Rico. The viral population of PRSV in Puerto Rico has $4 \%$ nucleotide and $5 \%$ amino acid diversity. Analysis of the coat protein (CP) amino acid sequence showed a variable amino terminal (N-terminal) region with a conserved aphid transmission motif and a variable EK repeat region. The core and carboxyl terminal (C-terminal) region were conserved. In the phylogenetic analysis, Puerto Rican isolates grouped independently of their geographical origin, with the exception of southern isolates that formed two separate subgroups and were the most divergent. Sequences of the $c p$ from the Puerto Rican isolates, when compared with sequences from other countries, showed least genetic distance with isolates from the United States and Australia, followed by other American and Caribbean isolates. The U.S. and Australian isolates are sister taxa to the Puerto Rican isolates in the phylogenetic tree. This suggests that PRSV from Puerto Rico and the isolates from the United States and Australia have a common origin thought to be from a Mexican population.
\end{abstract}

PRSV is the most serious, widespread, and damaging virus affecting papaya (Carica papaya L.) worldwide (Gonsalves, 1998; Teixeira da Silva et al., 2007). The PRSV belongs to the species-rich genus Potyvirus in Potyviridae and has a filamentous rod morphology composed of CP subunits enveloping the monopartite, linear, and positive single-stranded ribonucleic acid (RNA) genome (Chen et al., 2008; Olarte-Castillo et al., 2011). In terms of the structure of the $\mathrm{CP}$, there are three regions: $\mathrm{N}$-terminal, core, and C-terminal. The N-terminal is a highly variable region (Shukla et al., 1988) located in the surface of the virion. This region contains a vector transmission motif, DAG, conserved in potyviruses (Atreya et al., 1990; UrcuquiInchima et al., 2001), and an EK-rich region

\footnotetext{
Received for publication 17 Nov. 2015. Accepted for publication $8 \mathrm{Feb}$. 2016.

This study was funded by Howard Hughes Medical Institute grant to DS (award no. 52007566).

We thank Robert McPhail for helping in the collection of materials and serological testing and the U.S. Department of Agriculture-Tropical Agriculture Research Station (Mayagüez, Puerto Rico) for partial funding and for the use of facilities.

${ }^{1}$ Current address: South Carolina Forestry Commission, Columbia, SC 29212.

${ }^{2}$ Corresponding author. E-mail: dimuth.siritunga@ upr.edu.
}

with no biological function determined (Silva-Rosales et al., 2000). Conserved domains WCIEN, RQ, and QMKAA, common in potyvirus CPs, (Rodríguez-Martínez et al., 2014; Shukla et al., 1988; Wei et al., 2007) are found in the core and C-terminal regions (Shukla and Ward, 1989). These regions show a higher degree of conservation than the N-terminal region (Bateson et al., 1994). The variability in the latter is a common characteristic of potyviral CPs (Silva-Rosales et al., 2000). The domain RQ is a particularly important motif of the core region in the $\mathrm{CP}$ and is involved in viral particle assembly and cell-to-cell movement of potyviruses (Urcuqui-Inchima et al., 2001; Varrelmann and Maiss, 2000).

Plants that are host to PRSV include members of the Caricaceae, Cucurbitaceae, and Chenopodiaceae. The virus is transmitted nonpersistently by aphids and has two serologically indistinguishable biotypes: PRSV-W, which infects cucurbits but not papaya, and PRSV-P, which infects papaya and cucurbits. Infected plants develop symptoms in the leaves such as mosaic, shoestring appearance in the leaves, ringspots and bumps on the fruit, and stunting (OlarteCastillo et al., 2011; Tripathi et al., 2008). Furthermore, PRSV diseased fruits are affected by a decrease in their sugar content by $50 \%$ (Tripathi et al., 2008). This reduction in sugar content negatively affects fruit quality, yield, and revenues that could be obtained from production.

Natural resistance to PRSV has not been found in papaya (Lima et al., 2002) and vector control is not ideal since aphids do not colonize papaya (Fermin et al., 2010). As a result, several other control strategies have been developed with varying results. PRSV-tolerant varieties are available; however, their response to the virus can vary and be strain dependent, similar to crossprotected plants (Fermin et al., 2010; Teixeira da Silva et al., 2007). Other efforts have been directed toward breeding papaya with Vasconcellea species, a genus within Caricaeae with a natural resistance to PRSV (Siar et al., 2011). Crosses between $C$. papaya and Vasconcellea sp. have resulted in infertile progeny with reduced resistance to PRSV (Teixeira da Silva et al., 2007). Recently, Siar et al. (2011) reported a successful fertile PRSV-P resistant cross between both species. However, this is the first positive report after 50 years of unsuccessful attempts thus demonstrating that this is a strategy of very slow progress that will not be adequate in all situations.

Genetic engineering has played a major role and has proven to be the most successful method to control PRSV by using pathogenderived resistance. In the 1990s, a transgenic PRSV-resistant papaya variety was created with a chimeric $c p$ containing a sequence from a Hawaiian isolate (Tripathi et al., 2008). This event saved the Hawaiian industry and made papaya the first genetically enhanced fruit. However, it has been demonstrated that resistance is isolate specific and varies due to the nucleotide homology between the transgene and the PRSV isolate (Bateson et al., 1994; Davis and Ying, 2004; Lima et al., 2002; Tennant et al., 1994, 2005; Tripathi et al., 2008). Consequently, other transgenic cultivars have been developed in Florida, Brazil, Jamaica, Venezuela, and among others, using sense and antisense $c p$ transgenes of their respective PRSV isolate as an attempt to control the virus (Davis and Ying, 2004; Fermin et al., 2010; Tennant et al., 2005; Tripathi et al., 2008).

In Puerto Rico, PRSV was first reported affecting papaya by Adsuar (1946) who described it as a "Southern coast mosaic virus" that was restricted to the southern region of the island, particularly to the Ponce and Guánica municipalities (Riollano, 1951). Another virus, referred to as the "Isabela mosaic virus," was described in the northern part of the west region (Isabela municipality) as a different virus to the one in the south region. Rodríguez (1978) determined that both were the same virus with severe and attenuated symptoms, respectively, and that they were related to PRSV from Florida and Venezuela. Since then it has spread throughout the island (Escudero et al., 1994) devastating the production of papaya. Furthermore, papaya varieties developed in Puerto Rico (e.g., PR 6-65) are susceptible to PRSV (Crane et al., 1995; Davis and Ying, 2004; Singh et al., 1966). Reflective mulch has been used with 
positive results in decreasing the population of aphids that transmit PRSV (Robles et al., 2006). However, the vector acquires and transmits the virus for only a brief period (Tripathi et al., 2008) and does not remain on the plant. Consequently, the virus causes devastation and fields of papaya can be $100 \%$ infected nine months after planting, reducing production.

Puerto Rico's tropical climate has excellent conditions for continuous production of papaya throughout the year; however, production is nowhere near its potential. In 2013, $8,552,000 \mathrm{~kg}$ of papaya were produced, $148,000 \mathrm{~kg}$ less than the previous year. Production yield of papaya is at an all-time low with an annual growth rate of $-8.17 \%$ (FAOSTAT, 2013). Furthermore, Puerto Rico imports the majority of its papaya from other countries such as Costa Rica and the Dominican Republic (Commonwealth of Puerto Rico, 2013 and 2014), where fruit imports accounted for $682,514,482.47 \mathrm{~kg}$ in 2010 (DAPR, 2012). Thus, a high dependency on imports (Carro-Figueroa, 2002) and lack of an effective control have limited papaya production in the island. Information about the genetic diversity of PR-PRSV population would benefit the development of a durable control strategy, such as a transgenic PRSVresistant papaya. Therefore, the purpose of this study was to assess the genetic variation of PRSV using the $c p$ 's nucleotide and amino acid sequence of isolates collected from papaya and weed hosts from Cucurbitaceae in Puerto Rico. In addition, the genetic relationship between the PR-PRSV population and isolates from other countries is assessed as well.

\section{Materials and Methods}

PRSV isolates. A total of 62 leaf samples, 59 from C. papaya, two from Momordica charantia (L.), and one from Melothria pendula (L.), with PRSV-like symptoms were collected from different locations in Puerto Rico, which included private homes and commercial farms. Collections took place in 54 out of the 78 municipalities of the island, which were divided into 5 regions (Table 1). Tissue samples were tested for the presence of PRSV with the DAS-ELISA PRSV kit from Agdia Inc. (Elkhart, IN) and stored at $-80^{\circ} \mathrm{C}$. Positive samples were used for subsequent molecular analyses.

RNA isolation, reverse transcription polymerase chain reaction, and degenerate primer design. Tissue weighing $100 \mathrm{mg}$ was finely ground using liquid nitrogen. Total RNA was isolated using the RNeasy ${ }^{\circledR}$ Plant Mini Kit (Qiagen Inc., Hilden, Germany) according to manufacturer's instructions. Synthesis of single-stranded complimentary DNA (cDNA) from $100 \mathrm{ng}$ of RNA was performed using oligo (dT) and GoScript ${ }^{\mathrm{TM}}$ Reverse Transcriptase (Promega Corp., Madison, WI). To amplify the $c p$ from cDNA, a set of degenerate primers were designed based on a multiple sequence alignment with National Center for Biotechnology Information
(NCBI) Published $c p$ PRSV sequences from other countries (Table 2). Degenerate primers were selected at medium conserved regions and designed by assigning nonstandard bases at variable sites (Supplemental Table 1) according to the Nomenclature Committee of the International Union of Biochemistry (Cornish-Bowden, 1985). The combination that yielded the longest $c p$ amplicon (840 nt) was with primer JLS85 (5'-CTGTGGATGCTGGTTTGA-3') (Slightom, 1991) and reverse degenerate primer PRSV_Rv1.1 (5' -CMWRCCCAGRAGAGAGBG-3'). Subsequently, the $c p$ from PRSV ELISA-positive samples were amplified using the following polymerase chain reaction (PCR) conditions: denaturation cycle of $94{ }^{\circ} \mathrm{C}$ for $2 \mathrm{~min}$ followed by 40 cycles of amplification at $94{ }^{\circ} \mathrm{C}$ for $30 \mathrm{~s}, 50{ }^{\circ} \mathrm{C}$ for $1 \mathrm{~min}$ and $72{ }^{\circ} \mathrm{C}$ for $1 \mathrm{~min}$; a final $10 \mathrm{~min}$ extension was at $72{ }^{\circ} \mathrm{C}$. GoTaq ${ }^{\circledR}$ Flexi DNA polymerase from Promega Corp was used for PCR amplification in a $30 \mu \mathrm{L}$ reaction.

Sequencing and phylogenetic analysis. To sequence the $c p$, PCR products were cleaned using the QIAquick ${ }^{\circledR}$ PCR Purification Kit (Qiagen Inc.) according to manufacturer instructions. Subsequently, $c p$ amplicons were sequenced by the Genomic Sciences Laboratory at North Carolina State University (Raleigh, NC) using $\mathrm{ABI}^{\mathrm{TM}}$ 3730xl DNA Analyzer from Life Technologies (Carlsbad, CA). The 5' and $3^{\prime}$ ends were resequenced using internal sequencing primers PRSV_Rv5' $\left(5^{\prime}\right.$ GTGAYTGRGTKGCACGAG-3') and PRSV Fw3' (5'-CCGCGKTATGGRATYAAGAG-3') to obtain the full length of the 840nt PCR product.

Following sequencing, consensus sequences were made in BioEdit based on the sequences obtained. Multiple sequence alignments of the isolates' nucleotide (nt) and amino acid sequences (aa) were performed in Clustal W. Distances were measured as the number of base differences and amino acid substitutions per site, respectively, averaged overall sequence pairs in MEGA (version 6). The nt and aa distances were estimated by comparisons within the PR-PRSV isolates and between PRSV isolates from the world (Tables 1 and 2) in MEGA6. PRSV $c p$ sequences, published in GenBank (Table 2), were used to make sequence comparisons with PR-PRSV isolates. Diversity is expressed as a percentage based on the nucleotide and amino acid distances. A maximum likelihood phylogenetic tree was constructed, for both nucleotide and amino acid sequences, using 1000 bootstrap replicates. The $c p$ sequences from PR-PRSV isolates forming a cluster in the phylogenetic tree were grouped and compared with isolates in adjacent clusters to estimate and compare distances between them.

\section{Results}

PRSV cp sequence analysis. A total of 62 isolates collected in five different regions of Puerto Rico (Table 1) reacted positive to the PRSV DAS-ELISA, confirming their identity as the virus, and were amplified and sequenced with $c p$-specific primers. Comparisons of the amplified $c p$ sequences were used to estimate diversity in the PR-PRSV population as well as the $c p$ homology to isolates from the world (Table 2). The PR-PRSV isolates have an average distance of 0.042 (nt) and 0.054 (aa). Isolates from the United States have the least nucleotide distance to PR-PRSV ranging from 0.05 to 0.06 . The isolate USA-OK-W has the most similarity and least nucleotide and amino acid distance to the PR-PRSV population, followed by other U.S. isolates and Australian isolates. American and Caribbean isolates showed distances of $0.07-0.08$ at the nucleotide level and $0.09-0.10$ at amino acid to PR-PRSV. Asian isolates have less similarity and more genetic distance to the Puerto Rican isolates, where the isolate from Philippines had the greatest nucleotide and amino acid distance. In general, the amino acid distances of PR-PRSV to isolates from other countries was slightly less than those at the nucleotide level (Table 3).

Subsequently, the nucleotide sequences were translated to obtain the putative amino acid sequences. Four isolates per region were randomly chosen, as well as the first PR-PRSV NCBI Published isolate (PRI-P) (Table 2), out of the 62 total to represent the PR-PRSV population in the amino acid alignment (Fig. 1). The isolates differed mainly in the N-terminal region. The aphid transmission motif DAG was conserved in all of the isolates. A stretch of glutamic acid and lysine repeats (EK region) was found after the DAG triplet in four patterns of repeats. The first contained only one EK (II), the second contained a repeat of KEKEK (III), the third one contained a much larger repeat of KEKEKEK (IV), and the last one had a repeat of EKEK (IV). Compared with the PRI-P isolate, the second, third, and fourth repeat patterns of the EK region was variable for the PR-PRSV isolates determined in this study. The second repeat pattern included amino acid changes of the same type, glutamic acid to aspartic acid, in some isolates. A change from lysine to arginine and from lysine to asparagine is observed in the third and fourth patterns, respectively. The EK repeat patterns observed for the PR-PRSV isolates was the same as those found in the following isolates: USA-OK-W, USA-HI-P, MEX-P, and COL-P (data not shown). The conserved domains of WCIEN, RQ, and QMKAA, commonly found in potyviruses (RodríguezMartínez et al., 2014; Shukla et al., 1988; Wei et al., 2007), were present in the PR-PRSV isolates (boxes VI, VII, and IX, respectively) (Fig. 1).

Phylogenetic analysis of PR-PRSV cp. The amplified $c p$ sequence of the PR-PRSV isolates and its translated amino acid sequences were used to generate a maximum likelihood phylogenetic tree to assess the relationships of the Puerto Rican isolates and compare it to isolates from other countries (Fig. 2). The phylogenetic tree generated 
Table 1. Locality of the Puerto Rican Papaya ringspot virus isolates. A total of 62 isolates from Carica papaya (mainly), Momordica charantia, and Melothria pendula were used in this study to construct the nucleotide and amino acid alignments and phylogenetic trees. Accessions number assigned by National Center for Biotechnology Information GenBank for each Papaya ringspot virus isolate coat protein gene sequence is shown as well.

\begin{tabular}{|c|c|c|c|c|}
\hline Isolate name & Species & Municipality & Region & Accession no. \\
\hline $\begin{array}{l}\text { PRI_10 } \\
\end{array}$ & M. charantia & Isabela & West & KU130295 \\
\hline PRI_11 & C. papaya & Isabela & West & KU130296 \\
\hline PRI_16 & C. papaya & Aguada & West & KU130297 \\
\hline PRI_17 & M. pendula & Mayagüez & West & KU130298 \\
\hline PRI_22 & C. papaya & San Germán & West & KU130299 \\
\hline PRI_25 & C. papaya & San Germán & West & KU130300 \\
\hline PRI_31 & C. papaya & Guánica & West & KU130301 \\
\hline PRI_32 & C. papaya & Guánica & West & KU130302 \\
\hline PRI_37 & C. papaya & Yauco & South & KU130303 \\
\hline PRI_46 & M. charantia & Yauco & South & KU130304 \\
\hline PRI_50 & C. papaya & Guayanilla & South & KU130305 \\
\hline PRI_101 & C. papaya & Cayey & Central & KU130306 \\
\hline PRI_130 & C. papaya & Salinas & South & KU130307 \\
\hline PRI_136 & C. papaya & Guayama & South & KU130308 \\
\hline PRI_146 & C. papaya & Maunabo & East & KU130309 \\
\hline PRI_149 & C. papaya & Maunabo & East & KU130310 \\
\hline PRI_174 & C. papaya & Vieques & East & KU130311 \\
\hline PRI_201 & C. papaya & Guánica & West & KU130312 \\
\hline PRI_205 & C. papaya & Guánica & West & KU130313 \\
\hline PRI_207 & C. papaya & Aguada & West & KU130314 \\
\hline PRI_219 & C. papaya & Lares & Central & KU130315 \\
\hline PRI_220 & C. papaya & Lares & Central & KU130316 \\
\hline PRI_224 & C. papaya & Hatillo & North & KU130317 \\
\hline PRI_225 & C. papaya & Hatillo & North & KU130318 \\
\hline PRI_230 & C. papaya & Camuy & North & KU130319 \\
\hline PRI_232 & C. papaya & Sabana Grande & West & KU130320 \\
\hline PRI_233 & C. papaya & Sabana Grande & West & KU130321 \\
\hline PRI_235 & C. papaya & Juana Díaz & South & KU130322 \\
\hline PRI_236 & C. papaya & Barceloneta & North & KU130323 \\
\hline PRI_237 & C. papaya & Barceloneta & North & KU130324 \\
\hline PRI_239 & C. papaya & Barceloneta & North & KU130325 \\
\hline PRI_249 & C. papaya & Ciales & Central & KU130326 \\
\hline PRI_250 & C. papaya & Ciales & Central & KU130327 \\
\hline PRI_251 & C. papaya & Ciales & Central & KU130328 \\
\hline PRI_257 & C. papaya & Vega Baja & North & KU130329 \\
\hline PRI_260 & C. papaya & Juana Díaz & South & KU130330 \\
\hline PRI_263 & C. papaya & Santa Isabel & South & KU130331 \\
\hline PRI_266 & C. papaya & Santa Isabel & South & KU130332 \\
\hline PRI_269 & C. papaya & Santa Isabel & South & KU130333 \\
\hline PRI_270 & C. papaya & Santa Isabel & South & KU130334 \\
\hline PRI_272 & C. papaya & Juana Díaz & South & KU130335 \\
\hline PRI_274 & C. papaya & Juana Díaz & South & KU130336 \\
\hline PRI_275 & C. papaya & Ponce & South & KU130337 \\
\hline PRI_276 & C. papaya & Las Piedras & East & KU130338 \\
\hline PRI_277 & C. papaya & Las Piedras & East & KU130339 \\
\hline PRI_281 & C. papaya & Yabucoa & East & KU130340 \\
\hline PRI_282 & C. papaya & Humacao & East & KU130341 \\
\hline PRI_283 & C. papaya & Humacao & East & KU130342 \\
\hline PRI_284 & C. papaya & Humacao & East & KU130343 \\
\hline PRI_285 & C. papaya & Humacao & East & KU130344 \\
\hline PRI_297 & C. papaya & Juncos & East & KU130345 \\
\hline PRI_298 & C. papaya & Juncos & East & KU130346 \\
\hline PRI_299 & C. papaya & San Lorenzo & East & KU130347 \\
\hline PRI_302 & C. papaya & San Lorenzo & East & KU130348 \\
\hline PRI_303 & C. papaya & Ponce & South & KU130349 \\
\hline PRI_304 & C. papaya & Ponce & South & KU130350 \\
\hline PRI_307 & C. papaya & Peñuelas & South & KU130351 \\
\hline PRI_308 & C. papaya & Peñuelas & South & KU130352 \\
\hline PRI_316 & C. papaya & Orocovis & Central & KU130353 \\
\hline PRI_319 & C. papaya & Jayuya & Central & KU130354 \\
\hline PRI_320 & C. papaya & Jayuya & Central & KU130355 \\
\hline PRI_334 & C. papaya & Toa Alta & North & KU130356 \\
\hline
\end{tabular}

with the nucleotide sequences produced three major subgroups within the Puerto Rican isolates' group (Fig. 2A). The main subgroup (I) consisted of isolates from four of the five regions of Puerto Rico (north, west, east, and central). Furthermore, it is the subgroup with the least amount of island municipality of Puerto Rico that is separated by water from the main island, clustered with isolates within subgroup III that are from the eastern side of the south region. Likewise, isolates from the central region clustered with isolates from the south region. This is the case for PRI_101 and PRI_316 in subgroup II, and PRI_319 in subgroup III. Both subgroups had greater genetic distances among the isolates in them, compared with subgroup I. Isolates within subgroup II and III had 0.034 and 0.051 nucleotide distances, respectively. The phylogenetic tree generated with the translated amino acid sequence (Fig. 2B) of the $c p$ clustered similarly to the nucleotidebased tree (Fig. 2A). However, tree nodes are not supported by bootstrap values $(>80 \%)$ and we cannot establish subgroups within the PR-PRSV population. The first Puerto Rican isolate, PRI-P, published in GenBank (AF196838.1) clusters with subgroup II in Fig. 2A and with the rest of the isolates in Fig. 2B. Sequences obtained from PRSV isolates (PRI_10,PRI_17, PRI_46) of cucurbit hosts, M. charantia and M. pendula, clustered with those obtained from papaya (Fig. 2).

\section{Discussion}

The $c p$ nucleotide and amino acid sequences of 62 PRSV isolates from Puerto Rico (Table 1) were analyzed and compared with isolates from other countries (Table 2). Translation of the $c p$ nucleotide sequences of the Puerto Rican isolates showed a variable N-terminal region, which is typical for potyviruses (Bousalem et al., 2000; Jain et al., 2004; Silva-Rosales et al., 2000). The $\mathrm{N}$-terminal of the CP is exposed to the virion surface and contains the aphid transmission motif DAG (Atreya et al., 1990) and an EK region. The DAG motif was conserved in all PR-PRSV isolates. After the DAG motif is the EK region, which was highly variable in the PR-PRSV isolates (Fig. 1). This variability has been observed for other PRSV isolates in China (Wei et al., 2007), Mexico (SilvaRosales et al., 2000), Brazil and Cuba (Rodríguez-Martínez et al., 2014), and India (Jain et al., 2004; Srinivasulu and Sai Gopal, 2011) with differences in the number of EK box repeats between isolates from these countries. PR-PRSV isolates had the same EK repeats as isolates from the United States, Mexico, and Colombia. No biological function has been determined for this region; however, a possible relationship between the geographical distribution of the virus and their variability in this area has been suggested (Silva-Rosales et al., 2000). Potyvirus CP conserved domains WCIEN, RQ, and QMKAA (Rodríguez-Martínez et al., 2014; Shukla et al., 1988; Wei et al., 2007) were also found in the $\mathrm{CP}$ amino acid sequence of the PR-PRSV isolates (Fig. 1). Thus, the conservation of motifs involved in vector transmission and virion assembly in the amino acid sequence of PR-PRSV 
Table 2. Papaya ringspot virus isolates from different countries used in this study for sequence comparisons and phylogenetic trees as reported in the National Center for Biotechnology Information GenBank database.

\begin{tabular}{lllll}
\hline Isolate ID & Biotype & \multicolumn{1}{c}{ Country } & Accession no. & \multicolumn{1}{c}{ Reference } \\
\hline PRI & $\mathrm{P}$ & Puerto Rico & AF196838.1 & Davis and Ying, 1999 \\
USA-HI & $\mathrm{P}$ & Hawaii, United States & X67673.1 & Wang et al., 1994 \\
USA-OK & $\mathrm{W}$ & Oklahoma, United States & JN132413.1 & Abdalla and Ali, 2012 \\
USA-FL & $\mathrm{P}$ & Florida, United States & AF196839.1 & Davis and Ying, 1999 \\
USA-FL & $\mathrm{W}$ & Florida, United States & D00594.1 & Quemada et al., 1990; \\
& & & & Wang et al., 1994 \\
BRA & $\mathrm{P}$ & Brazil & AF344640.1 & Lima et al., 2002 \\
BRA & $\mathrm{W}$ & Brazil & AF344649.1 & Lima et al., 2002 \\
CUB & $\mathrm{P}$ & Cuba & DQ089482.1 & Unpublished \\
CUB & $\mathrm{W}$ & Cuba & KC768854.1 & Unpublished \\
COL & $\mathrm{P}$ & Colombia & HQ328797.1 & Olarte-Castillo et al., 2011 \\
MEX & $\mathrm{P}$ & Mexico & AJ012649.1 & Silva-Rosales et al., 2000 \\
JAM & $\mathrm{P}$ & Jamaica & DQ104823.1 & Chin et al., 2007b \\
VEN & $\mathrm{P}$ & Venezuela & EF189735.1 & Chin et al., 2007b \\
AUS & $\mathrm{P}$ & Australia & U14740.1 & Bateson et al., 1994 \\
AUS & $\mathrm{W}$ & Australia & U14744.1 & Bateson et al., 1994 \\
IND & $\mathrm{P}$ & India & AY238882.1 & Jain et al., 2004 \\
IND & $\mathrm{W}$ & India & JN979405.1 & Unpublished \\
PHP & $\mathrm{P}$ & Philippines & AF374863.1 & Unpublished \\
THA & $\mathrm{P}$ & Thailand & U14743.1 & Bateson et al., 1994 \\
LKA & $\mathrm{P}$ & Sri Lanka & U14741.1 & Bateson et al., 1994 \\
IDN & $\mathrm{P}$ & India & AF374865.1 & Unpublished \\
JPN & $\mathrm{P}$ & Japan & AB044339.1 & Unpublished \\
TWN & $\mathrm{W}$ & Taiwan & AY027812.1 & Unpublished \\
TWN & $\mathrm{P}$ & Taiwan & H78557.1 & Wang et al., 1994 \\
CHN & $\mathrm{P}$ & China & & Shen et al., 2014 \\
\hline
\end{tabular}

Table 3. Evolutionary divergence and similarity between Papaya ringspot virus (PRSV) isolates from the world and the Puerto Rican PRSV isolates from this study. Estimates were obtained by computing the overall distance between groups of isolates (Puerto Rico and other countries) in MEGA6.

\begin{tabular}{lcccc}
\hline & \multicolumn{2}{c}{ Nucleotide } & \multicolumn{2}{c}{ Amino acid } \\
\cline { 2 - 3 } Isolates & Distance & Similarity (\%) & Distance & Similarity (\%) \\
\hline USA-OK-W & 0.05 & 95 & 0.06 & 94 \\
USA-FL-P & 0.06 & 94 & 0.08 & 92 \\
USA-FL-W & 0.06 & 94 & 0.09 & 91 \\
USA-HI-P & 0.06 & 94 & 0.08 & 92 \\
AUS-P & 0.06 & 94 & 0.07 & 93 \\
AUS-W & 0.06 & 94 & 0.07 & 93 \\
CUB-P & 0.07 & 93 & 0.09 & 91 \\
CUB-W & 0.07 & 93 & 0.08 & 91 \\
COL-P & 0.07 & 93 & 0.09 & 92 \\
MEX-P & 0.07 & 93 & 0.08 & 90 \\
JAM-P & 0.07 & 93 & 0.10 & 90 \\
VEN-P & 0.07 & 93 & 0.10 & 90 \\
BRA-W & 9.08 & 92 & 0.10 & 90 \\
BRA-P & 9.08 & 0.10 & 90 \\
IND-P & 9.08 & 0.10 & 93 \\
IND-W & 92 & 0.07 & 89 \\
JPN-P & 9.07 & 0.11 & 88 \\
TWN-P & 0.10 & 93 & 86 \\
TWN-W & 0.11 & 90 & 0.12 & 89 \\
THA-P & 0.10 & 89 & 0.16 & 89 \\
CHN-P & 0.11 & 90 & 0.11 & 88 \\
IDN-P & 0.11 & 89 & 0.11 & 8.12 \\
LKA-P & 0.12 & 89 & 0.12 & \\
PHP-P & 0.13 & 96 & \\
\hline
\end{tabular}

isolates suggests that these functions are maintained.

At the amino acid level, the PR-PRSV isolates showed a diversity of $5.4 \%$. This diversity is possibly provided by the variable $\mathrm{N}$-terminal region (Fig. 1). This diversity is slightly higher than the nucleotide sequence diversity of the $c p(4.2 \%)$, which suggests that the nucleotide changes have influenced the amino acid sequence. A study of Mexican PRSV isolates by Noa-Carranza et al. (2007) showed high amino acid diversity as well as
The phylogenetic tree constructed with the $c p$ nucleotide sequence of the PR-PRSV isolates (Table 1) and PRSV isolates from the world (Table 2) showed three major subgroups within the PR isolates supported by bootstrap values (Fig. 2A). The PR-PRSV $c p$ subgrouping did not correlate in its entirety according to geographical origin within the island. Two of the major subgroups were composed of isolates from the southern region of Puerto Rico. Movement of hosts is evidenced by the fact that some isolates collected from the central region grouped with southern isolates (subgroups II and III). Moreover, an isolate collected in the island municipality of Vieques (east of Puerto Rico) clustered with isolates from the south/east region (subgroup III). The first subgroup contained isolates from four of the five regions of the island and were the less divergent, compared with the subgroups composed mainly of the southern isolates. The isolates formed clades in the phylogenetic tree generated with the $c p$ translated amino acid sequence (Fig. 2B) that are similar to the subgroups in the tree based in the nucleotide sequence (Fig. 2A). We were not able to establish subgroups because the nodes were not statistically significant (bootstrap values less than $80 \%$ ) in Fig. 2B. However, the phylogenetic relationships reflect the history and spread of PRSV in Puerto Rico. After the virus was reported for the first time in the island, two viruses were initially described as the "Southern coast mosaic virus" that produced severe symptoms and the "Isabela mosaic virus" in the northern side of the western region with attenuated symptoms (Riollano, 1951; Rodríguez, 1978). Subsequently, it was determined that they were both the same virus, PRSV, which was related to PRSV from Florida and Venezuela (Rodríguez, 1978). Even though almost 70 years have passed since its first report and descriptions, in the phylogenetic trees the south isolates grouped separately from those of the rest of the island (Fig. 2) PRSV was initially confined to the southwest area of Puerto Rico (between Ponce and Guánica municipalities), then spread to the northern part of the west region (Isabela municipality) and subsequently moved to the rest of the island (Escudero et al., 1994; Riollano, 1951; Rodríguez, 1978). This movement of south to west, west to north, and, subsequently, to the rest of the island is demonstrated in the phylogenetic tree of the $c p$ sequences where isolates from the south cluster with isolates from the west (subgroup II, Fig. 2A), and isolates from the northern side of the west region cluster with those of the rest of the island (subgroup I, Fig. 2A).

PRSV isolates from $M$. charantia and M. pendula cluster with those obtained from papaya (Fig. 2A and B). Momordica charantia is a common weed found in Puerto Rico (Rodrigues et al., 2012) shown to be a weed host reservoirs for PRSV-W (Adlerz, 1972b), PRS-P in Jamaica (Chin et al., 2007a), and other potyviruses (Adkins et al., 2008) Melothria pendula is also a weed host 


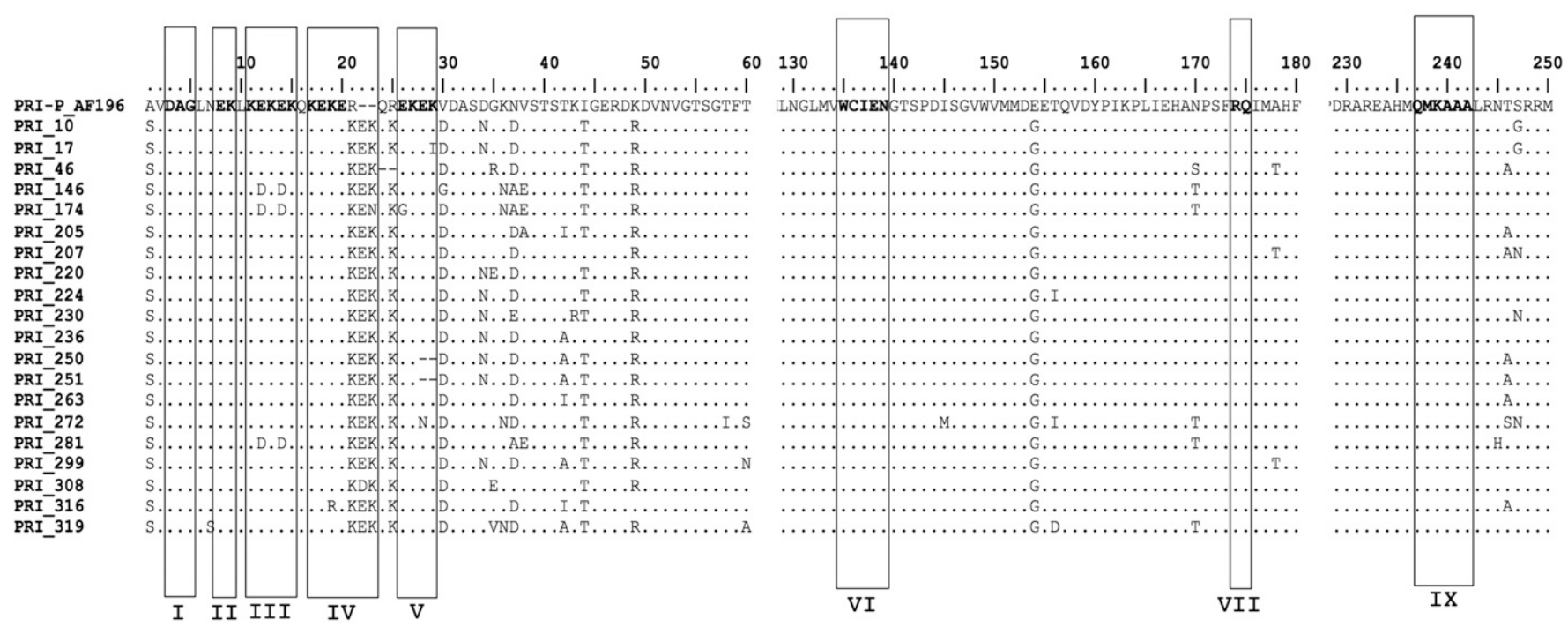

Fig. 1. Sections of the translated coat protein gene amino acid sequence alignment showing the different regions and conserved domains in Puerto Rican Papaya ringspot virus isolates from this study and previously published (AF196838.1). Ruler on top of the alignment indicates residue position with vertical bars on the fifth and tenth, and dots on every other one. Amino acid conservation in the alignment is represented by dots. Dashes indicate gaps or missing residues. Boxes highlight the conserved DAG domain (I, residue numbers 3-5) and variable EK repeats pattern (II-V, residue numbers 8-29) of the N-terminal region, the conserved domains WCIEN (VI, residue numbers 135-139), RQ (VII, residue numbers 184-186), QMKAA domains (IX, residue numbers 237-242) of the core and C-terminal. Multiple sequence alignments were conducted using ClustalW in MEGA6. The complete sequence is 283 amino acids in length.

reservoir for PRSV-W (Adlerz, 1972a) and Squash vein yellowing potyvirus (Adkins et al., 2008). The grouping of isolates from these cucurbit weed hosts shows that the W biotype cannot be differentiated from the P biotype based on the $c p$.

Previously to this study, there was one PR-PRSV sequence available in GenBank (Davis and Ying, 1999). Studies that analyzed the $c p$ diversity from different locations included this sequence in their phylogenetic trees as part of their global analysis of PRSV. The Puerto Rican sequence most commonly clustered with a Mexican isolate. Isolates from the United States and Australia were present in a sister cluster (Bateson et al., 2002; Davis and Ying, 1999; Lima et al., 2002). In our study, PR-PRSV are sister taxa to isolates from the United States, Australia, the Caribbean, and South America. The Mexican isolate used in the phylogenetic tree from this study clustered with an U.S. isolate (Fig. 2). The $c p$ from PR-PRSV isolates has less nucleotide and amino acid distance to isolates from the Australia and the United States (Table 3). Moreover, in the nucleotide and amino acid phylogenetic trees isolates from Australia and the United States cluster closely to the PR-PRSV isolates. This suggests that the PR-PRSV has a common origin to the isolates from these locations. In previous studies of PRSV's $c p$ show the U.S. and Australian isolates in the same cluster as Mexican isolates (Bateson et al., 2002; Silva-Rosales et al., 2000). It has led to the proposal of Mexico as the origin of PRSV from the United States and Australia (Bateson et al., 2002). However, in a study by OlarteCastillo et al. (2011) using a molecular model, the PR-PRSV sequence available at the time formed a cluster with Mexican isolates and a sister cluster with Colombian isolates. This suggested that the Colombian
PRSV has origins in the Caribbean or in Mexico. In our study, an isolate from Colombia clustered next to the PR-PRSV isolates (Fig. 2) and had the same genetic distance as an isolate from Mexico (Table 3). Therefore, it is possible that PR-PRSV has its origins from the Mexican population through the United States due to exports from the United States to Puerto Rico and the high homology of the $c p$ of PR-PRSV to isolates from the United States and Australia.

This study also found that isolates from India cluster within the American/Australian group and they have less genetic distances to PR-PRSV isolates, compared with other Asian isolates (Table 3); similar results have been obtained by other molecular studies of PRSV (Bateson et al., 2002; Jain et al., 2004; Olarte-Castillo et al., 2011; Silva-Rosales et al., 2000). A plausible explanation to these consistent results is the introduction of PRSV to the Americas, which is thought to have occurred through South America from one of two dispersal events that originated in India (Gibbs et al., 2008; Olarte-Castillo et al., 2011).

The PR-PRSV population showed a diversity of $4.2 \%$ in the nucleotide sequence of the $c p$. Interestingly, the amount of nucleotide diversity observed for PR-PRSV is similar to what was found in Venezuela and Mexico. The PRSV population showed a nucleotide diversity of $6.3 \%$ in Venezuela (Chin et al., 2007b; Fernández-Rodríguez et al., 2008) and $\approx 5 \%$ in Mexico (FernándezRodríguez et al., 2008; Silva-Rosales et al., 2000). Moreover, the diversity found for the PR-PRSV isolates is greater than that found in Jamaica at 2\% (Chin et al., 2007b) and Brazil at 3\% (Lima et al., 2002). However, recently Rodríguez-Martínez et al. (2014) found a greater diversity in Brazilian isolates (up to $9 \% \mathrm{nt}$ variability) than Lima et al. (2002), possibly due to the inclusion of an isolate from the Amazon. The similar amount in nucleotide diversity of the Jamaican and Brazilian PRSV populations is possibly explained by the finding that the origin of the Jamaican PRSV is in Brazil (OlarteCastillo et al., 2011).

The fact that the PR-PRSV isolates have a similar genetic diversity to countries that have greater geographical size and are not isolated is very interesting considering Puerto Rico's location and size. Also, it shows that diversity is not correlated with geographical isolation as suggested by Chin et al. (2007b) in a study comparing Jamaican and Venezuelan PRSV populations. Our results demonstrate that the introduction of the virus to Puerto Rico is not recent due to the high diversity found in the population. PRSV was first reported in Puerto Rico in the late 1940s (Adsuar, 1946) and has been present for 70 years in the island. The time since it was first detected possibly allowed for PR-PRSV to accumulate mutations and provides further support for the genetic diversity found. Divergent populations of PRSV have been suggested to be due to multiple migration events (FernándezRodríguez et al., 2008), which could have occurred in Puerto Rico due to its geographical location being readily accessible to all parts of the American continent. In addition, movement of hosts in the island certainly contributed to PR-PRSV's spread and diversity as evidenced in our phylogenetic tree by the clustering of central region's isolates with those of the south and an isolate from one of our island municipalities with those of the main island (Fig. 2). Natural selection and recombination are factors that also influence the genetic variability in viral populations (Fernández-Rodríguez et al., 2008) and their role in shaping PR-PRSV's population cannot be discarded. Furthermore, 


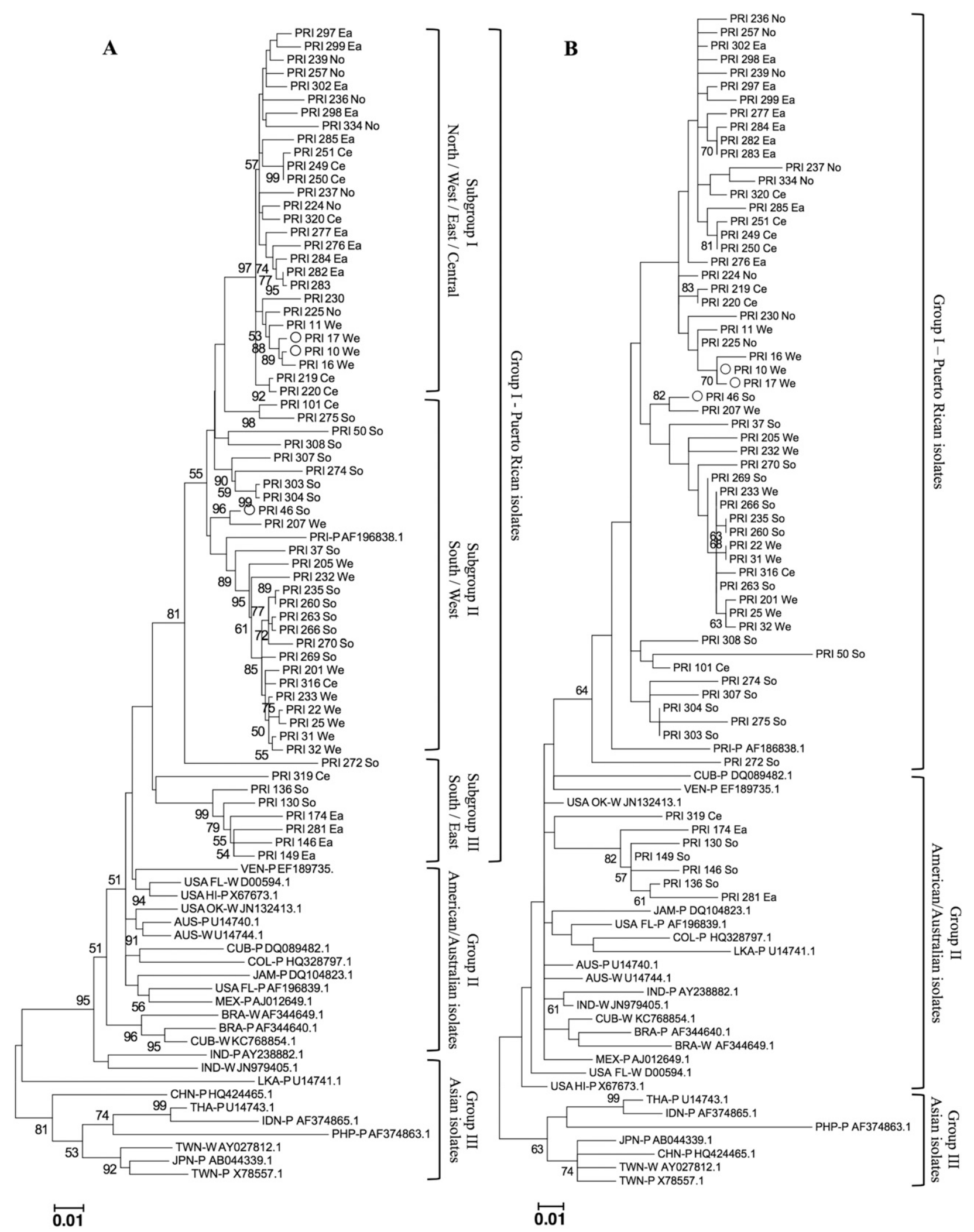

Fig. 2. Unrooted maximum likelihood phylogenetic trees of the (A) nucleotide and (B) amino acid sequence of the Papaya ringspot virus (PRSV)'s coat protein gene constructed with 1000 bootstrap replicates in MEGA6. Bootstraps values greater than 50\% are shown. Multiple sequence alignments for both nucleotide and amino acid sequences were performed in ClustalW. Taxons containing Puerto Rican PRSV isolates are named with isolate number and region: west (We), central (Ce), south (So), east (Ea), and north (No). PRSV-W isolates obtained from Momordica charantia and Melothria pendula are identified with an open circle. Information about the isolates used to generate these trees are detailed Tables 1 and 2.

RNA viruses are most susceptible to variability in their genomes due to the errorprone RNA-dependent RNA polymerase (Bousalem et al., 2000; Janssen et al., 2007).
Viral populations with a highly variable $c p$ have been found in the Potyviridae family and in the Potyvirus genus. Such is the case of Turnip mosaic virus, a virus with an ample host range and high variability in its $c p$ with nucleotide identities as low as $88.34 \%$ that varied depending on the host (Sánchez et al., 2003). Yam mosaic virus $c p$ gene was shown 
to have an average diversity of $11.5 \%$ (Bousalem et al., 2000). Zucchini yellow mosaic virus has a highly variable $c p$ with identity levels ranging between $85.4 \%$ and $100 \%$ (Pfosser and Baumann, 2002). Other members of the family, such as Sugarcane streak mosaic virus, a member of the recently accepted genus Poacevirus by the International Committee on Taxonomy of Viruses and former member of Potyvirus (Li et al., 2011), also demonstrated to have great variability in its $c p$ with $7.9 \%$ on average (Viswanathan et al., 2008).

To establish a strategy to control PRSV using transgenics in Puerto Rico, information about the diversity of the $c p$ of the PRSV population is of utmost importance. In fact, this was the gene used to genetically engineer papaya to be resistant to PRSV in many locations throughout the world (Davis and Ying, 2004; Fermin et al., 2010; Tennant et al., 2005; Tripathi et al., 2008). However, it has been found that resistance is dependent on the $c p$ homology between the transgene and the challenging virus (Bateson et al., 1994; Davis and Ying, 2004; Lima et al., 2002; Tennant et al., 1994, 2005; Tripathi et al., 2008). This study provided the necessary information about PRSV to implement an effective control strategy of the virus in Puerto Rico. We found that the island's population of PRSV is diverse and its southern isolates form separate cluster from those containing the majority of isolates from the rest of the island. It is possible that the southern isolates are a separate strain of PRSV. These isolates would be good candidates to be used in the design of a transgenic PRSV-resistant papaya for Puerto Rico for durable resistance against the virus. Studies have suggested the construction of a chimeric $c p$ transgene from divergent isolates from the same or different countries to obtain a broader resistance (Chin et al., 2007b; FernándezRodríguez et al., 2008). In addition, since PR-PRSV has high similarity to isolates from the United States, a PRSV-resistant transgenic papaya made for the main land United States could be tested in Puerto Rico.

\section{Literature Cited}

Abdalla, O.A. and A. Ali. 2012. Genetic diversity in the 3 -terminal region of papaya ringspot virus (PRSV-W) isolates from watermelon in Oklahoma. Arch. Virol. 156:405-412.

Adkins, S., S.E. Webb, C.A. Baker, and C.S. Kousik. 2008. Squash vein yellowing virus detected using nested polymerase chain reaction demonstrates that the cucurbit weed Momordica charantia is a reservoir host. Plant Dis. 92:1119-1123.

Adlerz, W.C. 1972a. Melothria pendula plants infected with Watermelon mosaic virus-1 as a source of inoculum for cucurbits in Collier County, Florida. J. Econ. Entomol. 65(5):1303-1306.

Adlerz, W.C. 1972b. Momordica charantia as a source of Watermelon mosaic virus-1 for cucurbit crops in Palm Beach County, Florida. Plant Dis. Rptr. 56:563-564.

Adsuar, J. 1946. Studies on virus diseases of papaya (Carica papaya) in Puerto Rico. I-Transmission of Papaya Mosaic. J. Agr. Univ. P R. 1:1-9.
Atreya, C.D., B. Raccah, and T.P. Pirone. 1990. A point mutation in the coat protein abolishes aphid transmissibility of a potyvirus. Virology 178(1):161-165.

Bousalem, M., E.J.P. Douzery, and D. Fargette. 2000. High genetic diversity, distant phylogenetic relationships and intraspecies recombination events among natural populations of Yam mosaic virus: A contribution to understanding potyvirus evolution. J. Gen. Virol. 81:243-255.

Carro-Figueroa, V. 2002. Agricultural decline and food import dependency in Puerto Rico: A historical perspective on the outcomes of postwar farm and food policies. Caribb. Stud. 30(2):77-107.

Chen, K., C. Chiang, J.A.J. Raja, F. Liu, C. Tai, and S. Yeh. 2008. A single amino acid of NIaPro of Papaya ringspot virus determines host specificity for infection of papaya. Mol. Plant Microbe Interact. 21(8):1046-1057.

Chin, M., M.H. Ahmad, and P. Tennant. 2007a. Momordica charantia is a weed host reservoir for Papaya ringspot virus type $\mathrm{P}$ in Jamaica. Plant Dis. 91(11):1518.

Chin, M., Y. Rojas, J. Moret, G. Fermin, P. Tennant, and D. Gonsalves. 2007b. Varying genetic diversity of Papaya ringspot virus isolates from two time-separated outbreaks in Jamaica and Venezuela. Arch. Virol. 152(11): 2101-2106.

Commonwealth of Puerto Rico. 2013. External Trade Statistics of Puerto Rico. Office of the Governor, Planning Board. 15 Oct. 2015. $<$ http://www.jp.gobierno.pr/>.

Commonwealth of Puerto Rico. 2014. External Trade Statistics of Puerto Rico. Office of the Governor, Planning Board. 15 Oct. 2015 $<\mathrm{http}: / /$ www.jp.gobierno.pr/>.

Cornish-Bowden, A. 1985. Nomenclature for incompletely specified bases in nucleic acid sequences: Recommendations 1984 . Nucl. Acids Res. 13(9):3021-3030.

Crane, J.H., B.A. Schaffer, and R.T. Mcmillan. 1995. Comparison of Papaya ringspot virus effects on 23 cultivars and 18 selections of papaya (Carica papaya) in South Florida. Proc. Fla. State Hort. Soc. 108:354-357.

Davis, M.J. and Z. Ying. 1999. Genetic diversity of the Papaya ringspot virus in Florida. Proc. Fla. State Hort. Soc. 112:194-196.

Davis, M.J. and Z. Ying. 2004. Development of papaya breeding lines with transgenic resistance to Papaya ringspot virus. Plant Dis. 88(4): 352-358.

Departamento de Agricultura de Puerto Rico (DAPR). 2012. Resumen de grupos alimenticios total 2010 . 12 Sept. 2015. <http://www.agricultura.pr.gov>.

Escudero, J., A. Acosta, L.V. Ramirez, I.B. Caloni, and G. Ruiz-Sifre. 1994. Yield of three papaya genotypes and their tolerance to Papaya ringspot virus in Puerto Rico. J. Agr. Univ. P R. 78(3-4): 111-121.

FAOSTAT. 2013. Food and Agriculture Organization of the United Nations, Statistics Division. 10 Sept. 2015. <http://faostat3.fao.org/>.

Fermin, G., L.T. Castro, and P. Tennant. 2010. $\mathrm{CP}$-transgenic and non-transgenic approaches for the control of Papaya ringspot: Current situation and challenges. Transgenic Plant J. 4(Special Issue 1):1-15.

Fernández-Rodríguez, T., L. Rubio, O. Carballo, and E. Marys. 2008. Genetic variation of papaya ringspot virus in Venezuela. Arch. Virol. 153(2):343-349.

Gibbs, A.J., K. Ohshima, M.J. Phillips, and M.J. Gibbs. 2008. The prehistory of potyviruses: Their initial radiation was during the dawn of agriculture. PLoS One 3(6):E2523.
Gonsalves, D. 1998. Control of papaya ringspot virus in papaya: A case study. Annu. Rev. Phytopathol. 36(1):415-437.

Jain, R.K., J. Sharma, A.S. Sivakumar, P.K. Sharma, A.S. Byadgi, A.K. Verma, and A. Varma. 2004. Variability in the coat protein gene of Papaya ringspot virus isolates from multiple locations in India. Arch. Virol. 149:2435-2442.

Janssen, D., L. Velasco, G. Martín, E. Segundo, and I.M. Cuadrado. 2007. Low genetic diversity among Cucumber vein yellowing virus isolates from Spain. Virus Genes 34:367-371.

Li, W., Z. He, S. Li, Y. Huang, Z. Zhang, D. Jiang, X. Wang, and Z. Luo. 2011. Molecular characterization of a new strain of sugarcane streak mosaic virus (SCSMV). Arch. Virol. 156(11):2010-2104.

Lima, R.C.A., M.T. Souza, Jr., G. Pio-Ribeiro, and J.A.A. Lima. 2002. Sequences of the coat protein gene from brazilian isolates of Papaya ringspot virus. Fitopatol. Bras. 27(2):174-180.

Noa-Carrazana, J.C., D. González-de-León, and L. Silva-Rosales. 2007. Molecular characterization of a severe isolate of papaya ringspot virus in Mexico and its relationship with other isolates. Virus Genes 35(1):109-117.

Olarte-Castillo, X.A., G. Fermin, J. Tabima, P.F. Tennant, M. Fuchs, R. Sierra, A.J. Bernal, and S. Restrepo. 2011. Phylogeography and molecular epidemiology of Papaya ringspot virus. Virus Res. 159:132-140.

Pfosser, M.F. and H. Baumann. 2002. Phylogeny and geographical differentiation of zucchini yellow mosaic virus isolates (Potyviridae) based on molecular analysis of the coat protein and part of the cytoplasmic inclusion protein genes. Arch. Virol. 147:1599-1609.

Quemada, H., B. L'Hostis, D. Gonsalves, I.M. Reardon, R. Heinrikson, E.L. Hiebert, L.C. Sieu and J.L. Slightom. 1990. The nucleotide sequences of the 3'-terminal regions of papaya ringspot virus strains $\mathrm{W}$ and P. J. Gen. Virol. 71:203-210.

Riollano, A. 1951. El cultivo y aprovechamiento de la papaya. Publicacion miscelanea 4. Estacion Experiemental Agricola, Univ. P. R. Rio Piedras, PR.

Robles, W., A. Patonja, E. Abreu, J. Peña, J. Ortiz, M.L. Lugo, M. Cortes, and R. Macchiavelli. 2006. El efecto de practicas agronomicas sobre el nivel poblacional de afidos y virosis en Carica papaya $\mathrm{L}$. Manejo Integrado de Plagas y Agroecología (Costa Rica) 77:38-43.

Rodrigues, J.C.V., I. Quintero-Lopez, and L. WesselBeaver. 2012. Potyviridae as a major challenge to growing cucurbits in Puerto Rico. Proc. X EUCARPIA Mtg. Genet. Breeding Cucurbitaceae, Antalya, Turkey, 15-18 Oct. 2012. p. 786-790.

Rodríguez, R.L. 1978. La virosis de la papaya (Carica papaya L.) en Puerto Rico. MS Thesis, Univ. P. R., Mayagüez. Abstr. SB317.P35 R63 1978 C.1.

Rodríguez-Martínez, D.R., P. Geraldino-Duarte, J. González-Olmedo, and A. dos Reis-Figueira. 2014. Molecular and biological studies of Papaya ringspot virus isolates from Brazil and Cuba. Amer. J. Agr. For. 2(5):209-218.

Sánchez, F., X. Wang, C.E. Jenner, J.A. Walsh, and F. Ponz. 2003. Strains of Turnip mosaic potyvirus as defined by the molecular analysis of the coat protein gene of the virus. Virus Res. 94:33-43.

Shen, W., D. Tuo, P. Yan, X. Li, and P. Zhou. 2014. Detection of Papaya leaf distortion mosaic virus by reverse-transcription loop-mediated 
isothermal amplification. J. Virol. Methods 195:174-179.

Shukla, D.D., P.M. Strike, S.L. Tracy, K.H. Gough, and C.W. Ward. 1988. The $\mathrm{N}$ and $\mathrm{C}$ termini of the coat proteins of potyviruses are surface-located and the $\mathrm{N}$ terminus contains the major virusspecific epitopes. J. Gen. Virol. 69:1497-1508.

Shukla, D.D. and C.W. Ward. 1989. Structure of potyvirus coat proteins and its application in the taxonomy of the potyvirus group. Adv. Virus Res. 36:273-314.

Siar, S.V., G.A. Beligan, A.J.C. Sajise, V.N. Villegas, and R.A. Drew. 2011. Papaya ringspot virus resistance in Carica papaya via introgression from Vasconcellea quercifolia. Euphytica 181(2):159-168.

Silva-Rosales, L., N. Becerra-Leor, S. Ruiz-Castro, D. Téliz-Ortiz, and J.C. Noa-Carrazana. 2000. Coat protein sequence comparisons of three Mexican isolates of papaya ringspot virus with other geographical isolates reveal a close relationship to American and Australian isolates. Arch. Virol. 145:835-843.

Singh-Dhaliwal, T., A. Perez-Lopez, and J. LopezGarcía. 1966. Selecciones prometedoras de papaya para pruebas comerciales en Puerto Rico.
Publicacion miscelanea 57. Estacion Experiemental Agricola, Univ. P. R. Rio Piedras, PR.

Slightom, J.L. 1991. Custom polymerase-chainreaction engineering of a plant expression vector. Gene 100:251-255.

Srinivasulu, M. and D.V.R. Sai Gopal. 2011. Coat protein sequence comparison of south Indian isolates of Papaya ringspot virus with other Indian subcontinent isolates. Phytopathol. Mediterr. 50:359-367.

Tennant, P., M.H. Ahmad, and D. Gonsalves. 2005 Field resistance of coat protein transgenic papaya to Papaya ringspot virus in Jamaica. Plant Dis. 89(8):841-847.

Tennant, P., C. Gonsalves, K. Ling, M. Fitch, R. Manshardt, J.L. Slightom, and D. Gonsalves. 1994. Differential protection against papaya ringspot virus in coat protein gene transgenic papaya and classically cross-protected papaya. Phytopathology 84(11):1359-1366.

Teixeira da Silva, J.A., Z. Rashid, D. Tan, D. Nhut, A. Sivakumar, A. Gera, M.T. Souza, Jr., and P.F. Tennant. 2007. Papaya (Carica papaya L.) biology and biotechnology. Tree For. Sci. Biotechnol. 1(1):47-73.

Tripathi, S., J.Y. Suzuki, S.A. Ferreira, and D. Gonsalves. 2008. Papaya ringspot virus-P:
Characteristics, pathogenicity, sequence variability and control. Mol. Plant Pathol. 9(3): 269-280.

Urcuqui-Inchima, S., A.L. Haenni, and F. Bernardi. 2001. Potyvirus proteins: A wealth of functions. Virus Res. 74(1-2):157-175.

Varrelmann, M. and E. Maiss. 2000. Mutations in the coat protein gene of Plum pox virus suppress particle assembly, heterologous encapsidation and complementation in transgenic plants of Nicotiana benthamiana. J. Gen. Virol. 81:567-576.

Viswanathan, R., M. Balamuralikrishnan, and R. Karuppaiah. 2008. Characterization and genetic diversity of sugarcane streak mosaic virus in sugarcane. Virus Genes 36:553-564.

Wang, C.H., H.J. Bau, and S.D. Yeh. 1994. Comparison of the nuclear inclusion $\mathrm{b}$ protein and coat protein genes of five papaya ringspot virus strains distinct in geographic origin and pathogenicity. Phytopathology 84(10):12051210 .

Wei, J.Y., D.B. Liu, X.Y. Li, and P. Zhou. 2007. Variation in the coat protein gene of Papaya ringspot virus isolates from multiple locations of China. J. Integr. Plant Biol. 49(7): 1062-1069. 
Supplemental Table 1. Nonstandard bases for variable sites in a nucleotide sequence according to the Nomenclature Committee of the International Union of Biochemistry (CornishBowden, 1985). A: adenine, G: guanine, C: cytosine, T: thymine.

\begin{tabular}{ll}
\hline Nonstandard bases & Variable site \\
\hline $\mathrm{R}$ & $\mathrm{A}, \mathrm{G}$ \\
$\mathrm{Y}$ & $\mathrm{C}, \mathrm{T}$ \\
$\mathrm{M}$ & $\mathrm{A}, \mathrm{C}$ \\
$\mathrm{K}$ & $\mathrm{G}, \mathrm{T}$ \\
$\mathrm{S}$ & $\mathrm{C}, \mathrm{G}$ \\
$\mathrm{W}$ & $\mathrm{A}, \mathrm{T}$ \\
$\mathrm{H}$ & $\mathrm{A}, \mathrm{C}, \mathrm{T}$ \\
$\mathrm{B}$ & $\mathrm{C}, \mathrm{G}, \mathrm{T}$ \\
$\mathrm{V}$ & $\mathrm{A}, \mathrm{C}, \mathrm{G}$ \\
$\mathrm{D}$ & $\mathrm{A}, \mathrm{G}, \mathrm{T}$ \\
$\mathrm{N}$ & $\mathrm{A}, \mathrm{C}, \mathrm{G}, \mathrm{T}$ \\
\hline
\end{tabular}

